\title{
FOUR PHASE INTERLEAVED BOOST CONVERTER - ANALYSIS AND VERIFICATION
}

\author{
Slavomir KASCAK, Michal PRAZENICA, Miriam JARABICOVA, Roman KONARIK \\ Department of Mechatronics and Electronics, Faculty of Electrical Engineering, \\ University of Zilina, Univerzitna 1, 01026 Zilina, Slovak Republic, E-mail: slavomir.kascak@fel.uniza.sk
}

\begin{abstract}
This paper deals with an analysis of four phase interleaved DC-DC converter for higher power application in continuous conduction mode. The interleaved topology is widely used due to their advantage as lower input current ripple which means volume reduction of input capacitor. The current ripple equation of an input current for the boost operation mode and the ripple current in individual phases of the interleaved converter using uncoupled inductor are shown. The theoretical equations are supplemented by the simulation results using Spice simulator and by measurement on the interleaved converter.
\end{abstract}

Keywords: interleaved boost converter, uncoupled inductor, simulation, measurement

\section{INTRODUCTION}

Nowadays, the interleaved topologies are widely used in various sectors of industry, ranging from small output power to several hundred kilowatts for their attractive features [1] - [6], [10], [13] - [15].

The interleaved topologies are frequently used for following applications, such as an active PFC filter for improvement of electromagnetic compatibility [7] - [9]. The next advantage is present in VRM application in the motherboard of a personal computer, where the output voltage is about $1 \mathrm{~V}$, but output current is several tens of amperes [10]. The high output current can be divided into several channels of the multiphase converter without using power devices with higher current ratings, which leads to decreased power losses. Another advantage is a highfrequency operation for the input current, but the switching frequency of power devices is n-times lower for the n-channel interleaved converter. For achievement of the same current ripple, it is possible to use smaller inductors in comparison to classical converter but the transient response of the interleaved will be faster, and therefore the dynamics will be better. The abovementioned properties and many others contribute to the increase of the power density [1], [4].

The multiphase converter also has several disadvantageous, such as more active and/or passive components and complexity of the control algorithm. Currently, the microprocessors or digital signal controllers are powerful, and this disadvantage is irrelevant.

Therefore, in this paper, the advantageous features of the interleaved topology will be analysed on four phase boost DC-DC converter. The motivation for preparing this article is utilizing of the converter as an interface between batteries or supercapacitor and a three-phase inverter for an $\mathrm{AC}$ motor drive system in Electric Vehicle (EV) [4], [6], [11] - [15].

This paper is divided as follows: Firstly, the theoretical analysis is investigated for different operational mode depending on the value of the duty cycle. The switching interval is accordingly divided into four intervals. In addition, the equation of the inductor current ripple and input current ripple are given in this part. Secondly, the simulation analysis will be performed to compare current ripples with a calculated value. And finally, the measured data of the input current ripple and inductor ripple will be given proportionally as a ratio of input current ripple to inductor current ripple. The theoretical, simulated and measured ratio will be plotted in a graph.

The purpose of the paper is to examine operating mode of the converter with the lowest input current ripple comparing to inductor currents and then determine the proper range of duty cycle.

\section{ANALYSIS OF FOUR-PHASE INTERLEAVED BOOST CONVERTER}

The inductor ripple currents of the four-phase interleaved boost converter depicted in Fig. 1 are analyzed in this section. Based on these currents is calculated an input current ripple as a sum of them. These characteristics are analyzed separately for operation modes because the applied voltages depend on ranges of the duty ratio $D \leq 1 / 4,1 / 4 \leq D \leq$ $1 / 2,1 / 2 \leq D \leq 3 / 4,3 / 4 \leq D \leq 1$.

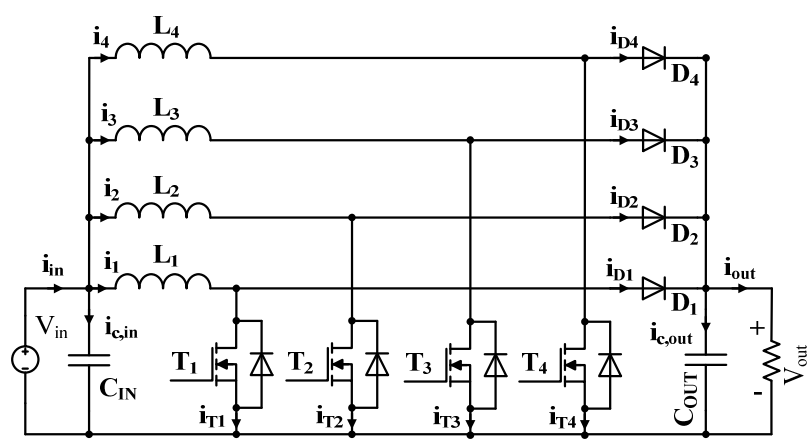

Fig. 1 Four-phase interleaved boost converter

Figures 2, 3, 4 and 5 show the inductor current waveforms for duty ratio less than $1 / 4$, between $1 / 4$ and $1 / 2,1 / 2$ and $3 / 4$, and greater than $3 / 4$, respectively, where $S_{1}, S_{2}, S_{3}$ and $S_{4}$ are switching signals; $i_{1}, i_{2}, i_{3}$ and $i_{4}$ are the inductor currents; $I_{I p p}, I_{2 p p}, I_{3 p p}$, and $I_{4 p p}$ are the peak to peak amplitudes or current ripples of the $i_{1}, i_{2}, i_{3}$ and $i_{4}$, respectively and $i_{\text {in }}$ are the input current, which is the sum of four inductor currents.

Here, the equations for inductor current ripples are investigated and they are given for $\mathrm{D} \leq 1 / 4$. The equation (1) determines an increasing character of the inductor current 
$i_{1}$ and on the other hand the equations (2), (3) and (4) a decreasing character of the inductor currents $i_{2}, i_{3}$, and $i_{4}$.

$$
\begin{aligned}
& \Delta I_{1 p p}=I_{1 p p}=\frac{V_{i n}}{L} D T_{S}, \\
& \Delta I_{2 p p}=\frac{V_{i n}}{L}\left(1-\frac{1}{1-D}\right) D T_{S}, \\
& \Delta I_{3 p p}=\frac{V_{\text {in }}}{L}\left(1-\frac{1}{1-D}\right) D T_{S}, \\
& \Delta I_{4 p p}=\frac{V_{\text {in }}}{L}\left(1-\frac{1}{1-D}\right) D T_{S}, \\
& I_{\text {inpp }}=I_{1 p p}+\Delta I_{2 p p}+\Delta I_{3 p p}+\Delta I_{4 p p}= \\
& \frac{V_{\text {in }}}{L} D T_{S}\left(\frac{1-4 D}{1-D}\right)=\frac{V_{o u t}}{L} D T_{S}(1-4 D),
\end{aligned}
$$

where $V_{\text {in }}$ and $V_{\text {out }}$ are the input and output voltages of the interleaved converter, $D$ is the duty ratio, and $L$ is the inductor value in Henrys.

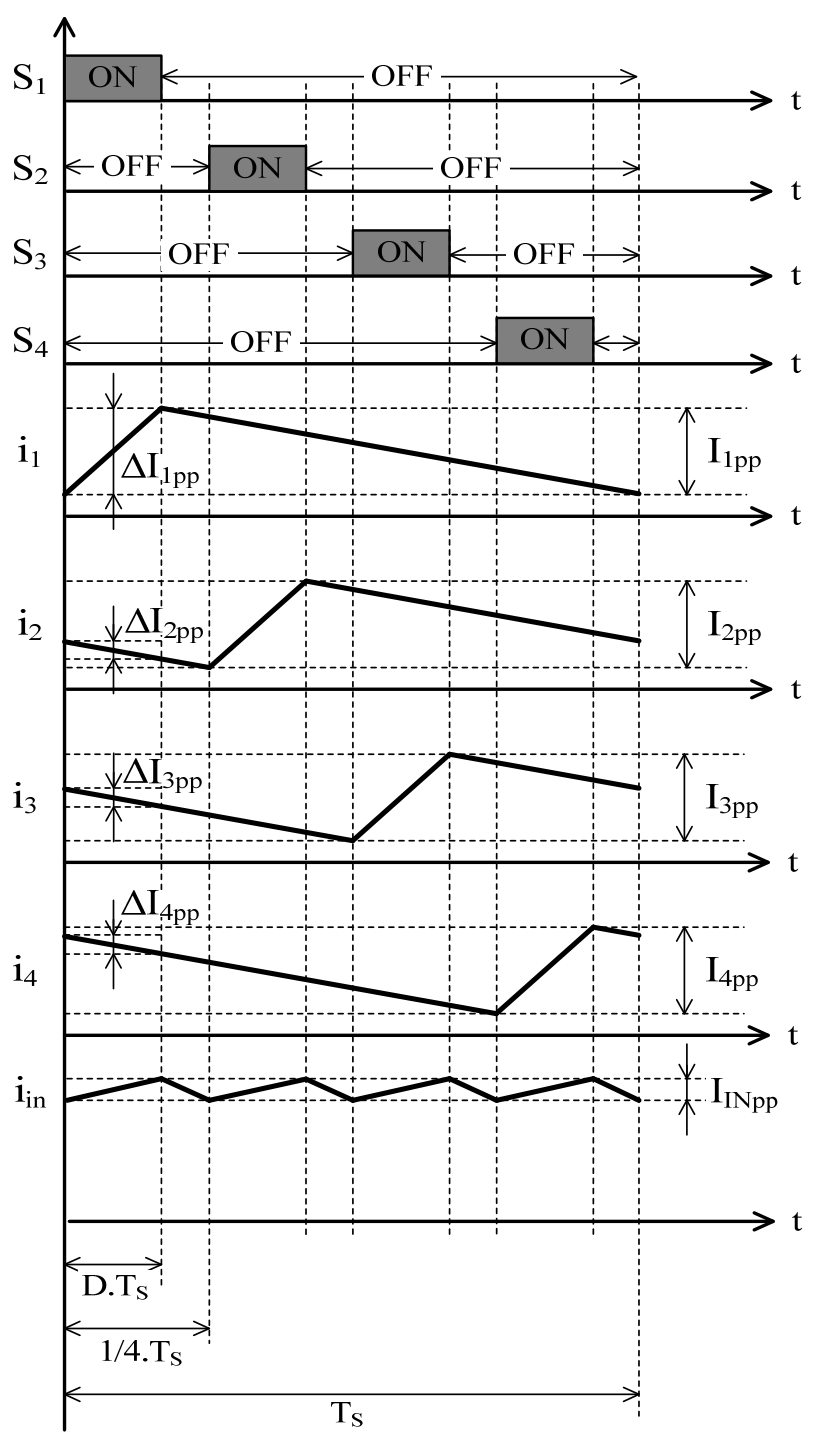

Fig. 2 Inductors current waveforms in range of duty ratio less than $1 / 4$

As can be seen from Fig. 2 to Fig. 5 the equations (1) (20) are dependent on the rise time of the input current which it expresses the value of the input current ripple. According this statement the inductor current ripples $\left(I_{l p p}\right.$ $\left.I_{4 p p}\right)$ are different from the current ripples $\left(\Delta I_{l p p}-\Delta I_{4 p p}\right)$, except one case of (1).

Similarly, the equations for another interval of the duty ratio $1 / 4 \leq \mathrm{D} \leq 1 / 2$ are as follows:

$$
\begin{aligned}
& \Delta I_{1 p p}=\frac{V_{\text {in }}}{L} D T_{S}, \\
& \Delta I_{2 p p}=\frac{V_{\text {in }}}{L}\left(1-\frac{1}{1-D}\right) D T_{S}, \\
& \Delta I_{3 p p}=\frac{V_{\text {in }}}{L}\left(1-\frac{1}{1-D}\right) D T_{S}, \\
& \Delta I_{4 p p}=\frac{V_{\text {in }}}{L} D T_{S}, \\
& I_{\text {inpp }}=\Delta I_{1 p p}+\Delta I_{2 p p}+\Delta I_{3 p p}+\Delta I_{4 p p}= \\
& -\frac{V_{\text {in }}}{2 L} T_{S}\left(\frac{8 D^{2}-6 D+1}{1-D}\right)= \\
& -\frac{V_{\text {out }}}{2 L} T_{S}\left(8 D^{2}-6 D+1\right) .
\end{aligned}
$$

The value of the input current is increased until two switches in two different phases are in on-state; in the all next states of the switches, the input current has a decreasing character, as can be seen in Fig. 3.

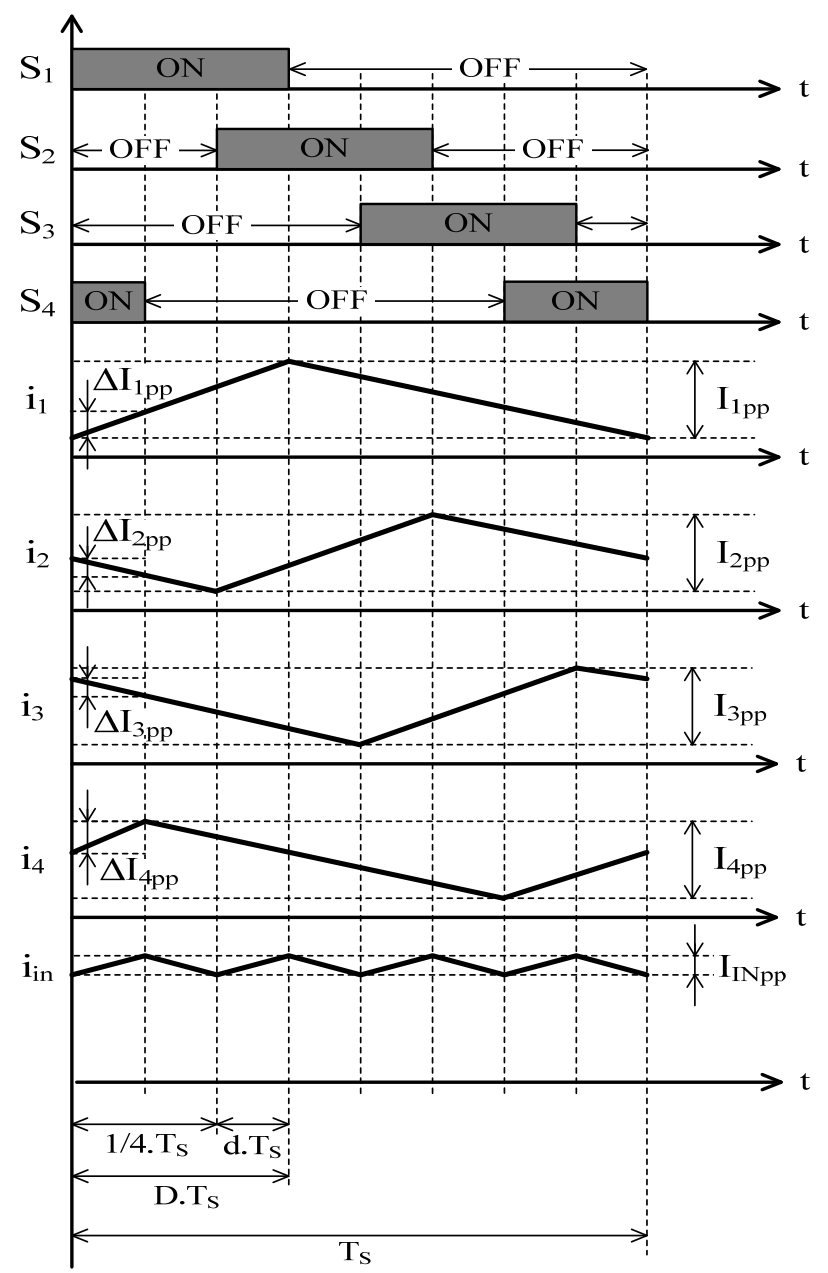

Fig. 3 Inductor current waveforms in range of duty ratio $1 / 4 \leq \mathrm{D} \leq 1 / 2$ 
In the third interval $1 / 2 \leq \mathrm{D} \leq 3 / 4$, when three switches are in on-state the inductor current is increasing and therefore the input current is also increasing. When only two switches are in on-state, the input current is decreasing, which is shown in the following equations and depicted in Fig. 4.

$$
\begin{aligned}
& \Delta I_{1 p p}=\frac{V_{\text {in }}}{L} D T_{S}, \\
& \Delta I_{2 p p}=\frac{V_{\text {in }}}{L}\left(1-\frac{1}{1-D}\right) D T_{S}, \\
& \Delta I_{3 p p}=\frac{V_{\text {in }}}{L} D T_{S}, \\
& \Delta I_{4 p p}=\frac{V_{\text {in }}}{L} D T_{S}, \\
& I_{\text {inpp }}=\Delta I_{1 p p}+\Delta I_{2 p p}+\Delta I_{3 p p}+\Delta I_{4 p p}= \\
& -\frac{V_{\text {in }}}{2 L} T_{S}\left(\frac{8 D^{2}-10 D+3}{1-D}\right)= \\
& -\frac{V_{\text {out }}}{2 L} T_{S}\left(8 D^{2}-10 D+3\right) .
\end{aligned}
$$

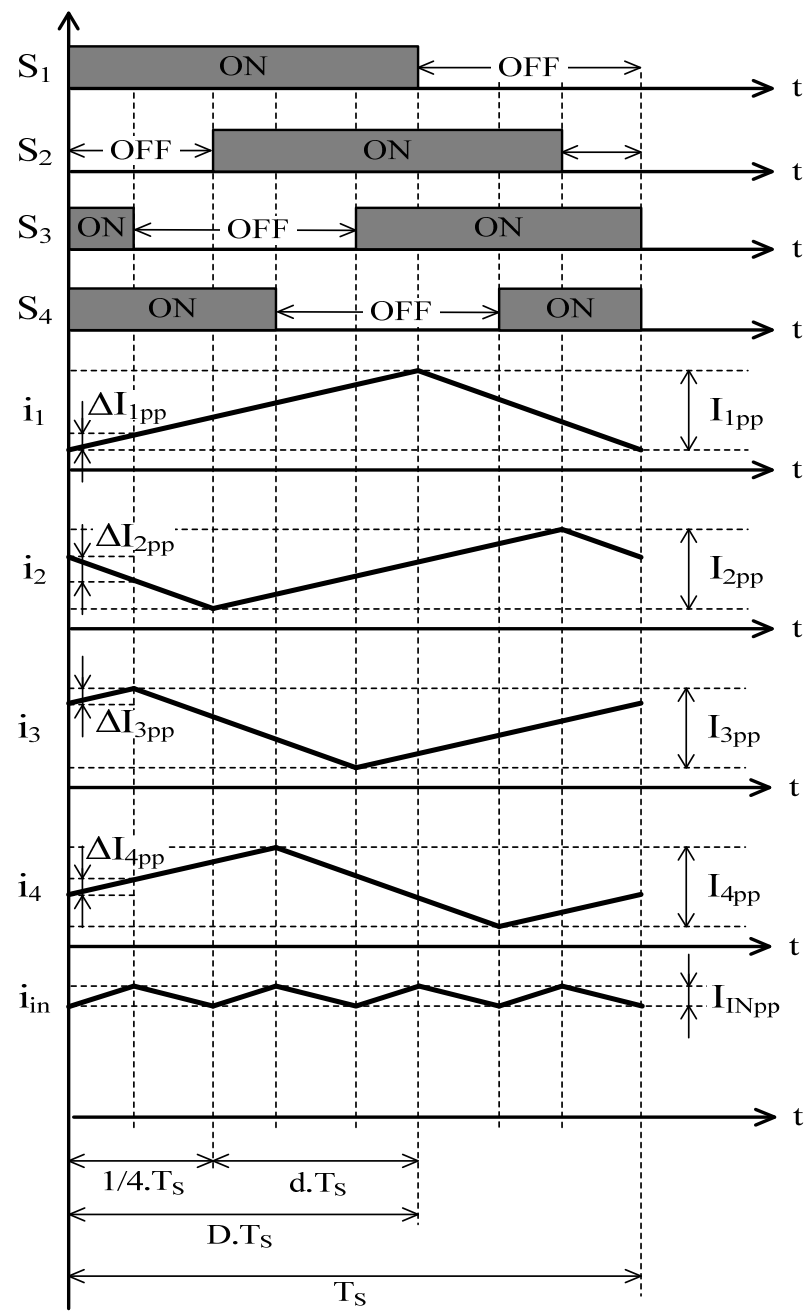

Fig. 4 Inductor current waveforms in range of duty ratio $1 / 2 \leq \mathrm{D} \leq 3 / 4$

In the same manner, as in previous intervals, in the fourth interval $3 / 4 \leq D \leq 1$, when four switchers are in on- state the inductor current is increasing, and if only one switch is in off-state, the input current is decreasing.

$$
\begin{aligned}
& \Delta I_{1 p p}=\frac{V_{\text {in }}}{L} D T_{S}, \\
& \Delta I_{2 p p}=\frac{V_{\text {in }}}{L} D T_{S}, \\
& \Delta I_{3 p p}=\frac{V_{\text {in }}}{L} D T_{S}, \\
& \Delta I_{4 p p}=\frac{V_{\text {in }}}{L} D T_{S}, \\
& I_{\text {inpp }}=\Delta I_{1 p p}+\Delta I_{2 p p}+\Delta I_{3 p p}+\Delta I_{4 p p}= \\
& \frac{V_{\text {in }}}{L} T_{S}(3 D-2) .
\end{aligned}
$$

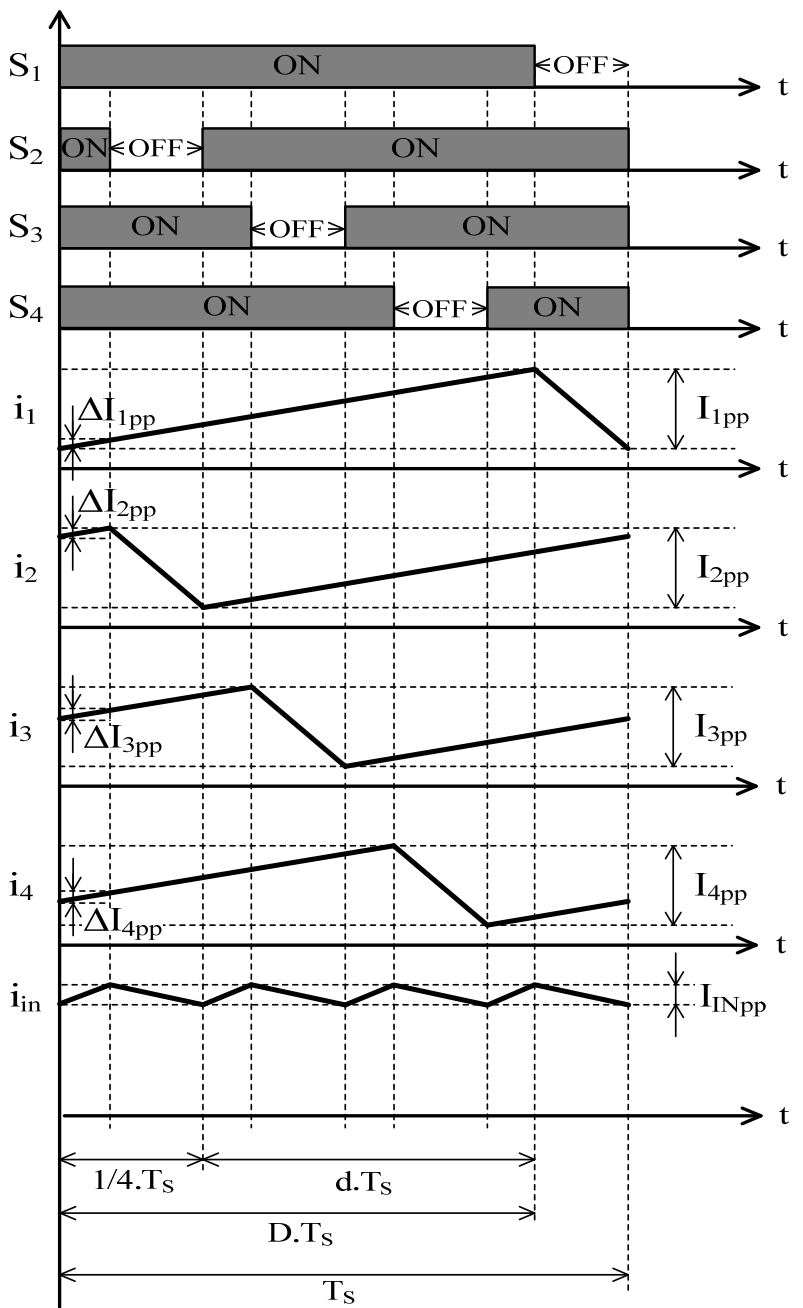

Fig. 5 Inductor current waveforms in range of duty ratio $3 / 4 \leq \mathrm{D} \leq 1$

As can be seen from the previous figures the frequency of the input current ripple is four times higher as compared to the inductor current what yields to reduced current ripple. If we look at equations (1) - (20) the current ripples are dependent on the value of $V_{\text {in }}$ or $V_{\text {out }}$, duty ratio $D$, inductor value $L$ and switching period $T_{S}$. However, the ratio of $I_{\text {inpp }}$ and $I_{n p p}(\mathrm{n}=1,2,3$ or 4 is the number of the phase) is only dependent on the duty ratio $\mathrm{D}$. Therefore, in the next chapter is analysed only relative value of input current ripple and inductor current ripple. 


\section{EXPERIMENTAL VERIFICATION}

The test stand depicted in Fig. 6 consist of 8 switches converter, four non-coupled inductors, power analyser, power supplies and electronic load. The control algorithm of the converter was only in open loop and PWM signals for driving transistors was implemented by the TI microcontroller TMS320F28069M. The parameters of the converter stand are given in Table 1.

Table 1 Parameters of the interleaved converter

\begin{tabular}{|l|l|}
\hline Parameter & Value \\
\hline Inductor & $430 \mu \mathrm{H}$ \\
\hline Output power & according the load \\
\hline Input voltage & $50 \mathrm{~V}$ \\
\hline Output voltage & According duty ratio and load \\
\hline
\end{tabular}

The input or output voltage of the converter was not so important because investigating characteristic of current ripple ratio does not depend on these parameters. Also the converter stage was not optimized for efficiency measurement; the investigation was only oriented to determine a current ripple in different conditions.

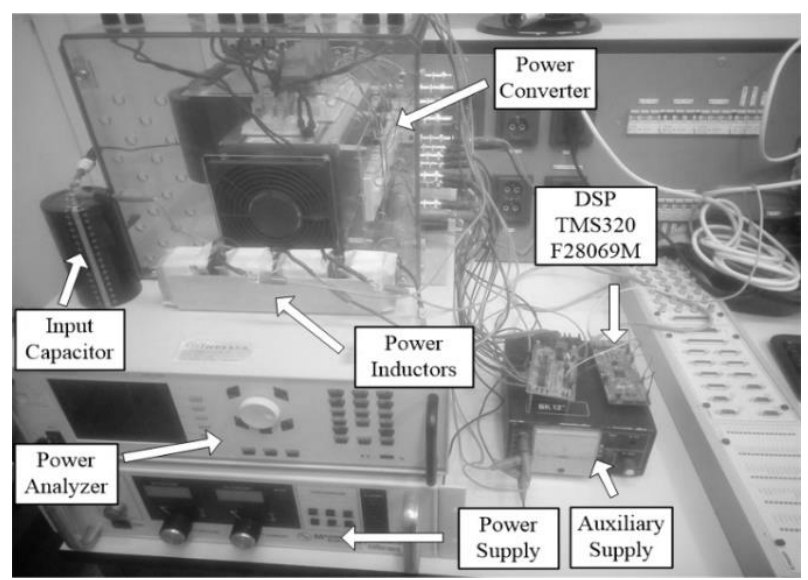

Fig. 6 Test stand of four phase interleaved boost converter

The AC components of simulated and measured input and inductor currents are shown in the following figures Fig. 7 - Fig. 12.

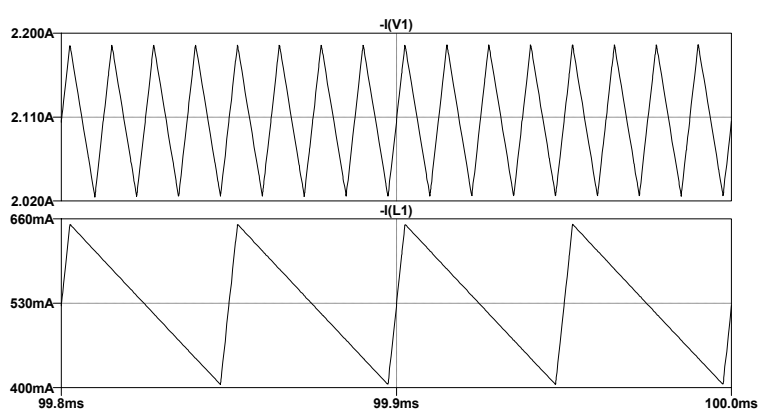

Fig. 7 Simulated waveforms of input current (up) and inductor current (down) with $\mathrm{D}=0.1$

Then, from simulation results (Fig. 9) and measurement (Fig. 10) is seen that the ripple of the input current is not zero, but in comparison to its dc component as shown in Fig. 9 should be considered as zero.
Therefore, also the measured ratio around duty cycles $0.25,0.5$ and 0.75 should be considered as zero. Then, Fig. 13 shows the comparison of the theoretical, simulated and measured ratio of input current ripple to inductor current ripple within whole range of duty cycle.

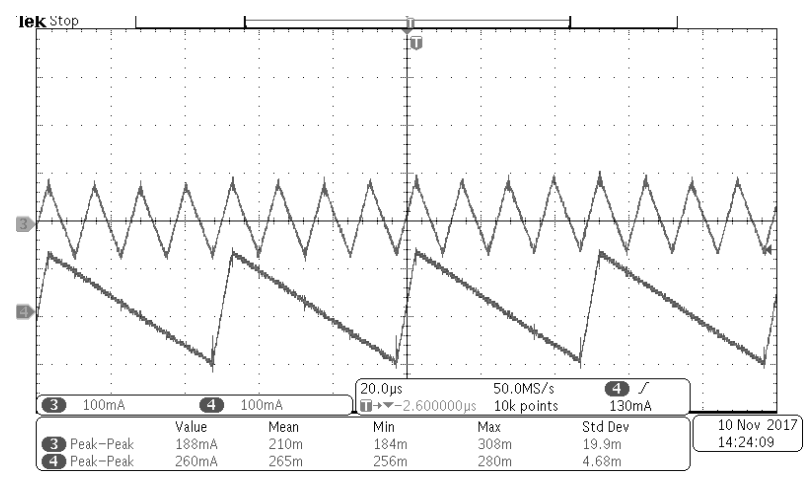

Fig. 8 Measured waveforms of input current (up) and inductor current (down) with $\mathrm{D}=0.1$

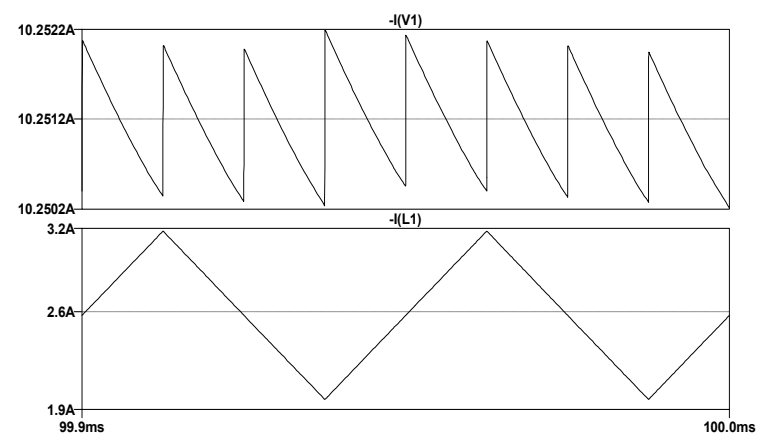

Fig. 9 Simulated waveforms of input current (up) and inductor current (down) with $\mathrm{D}=0.1$

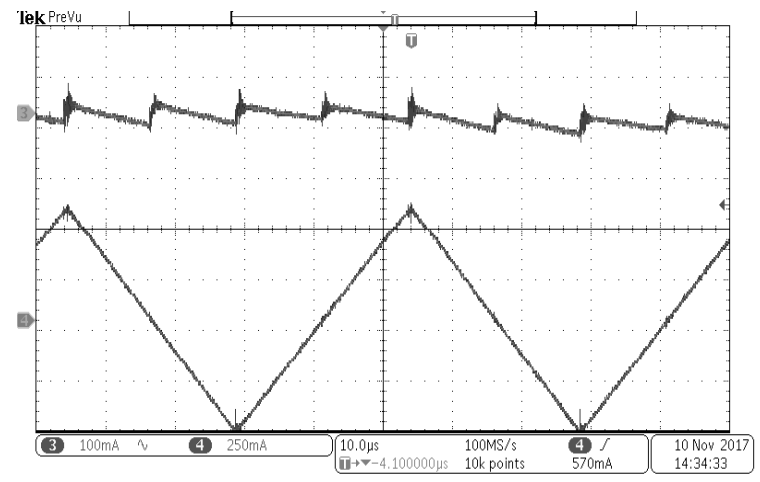

Fig. 10 Measured waveforms of input current (magenta) and inductor current (green) with $\mathrm{D}=0.5$

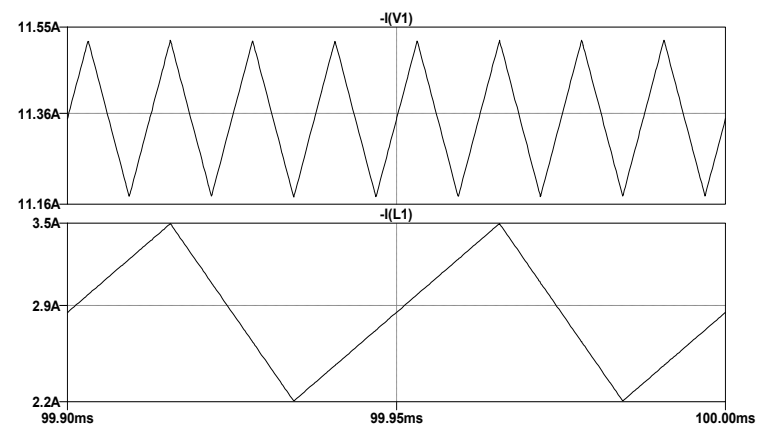

Fig. 11 Simulated waveforms of input current (up) and inductor current (down) with $\mathrm{D}=0.1$ 


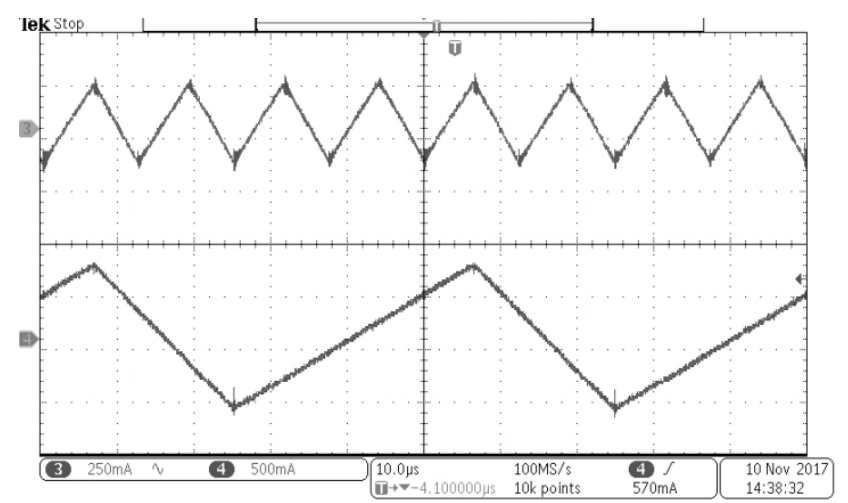

Fig. 12 Measured waveforms of input current (magenta) and inductor current (green) with $\mathrm{D}=0.625$

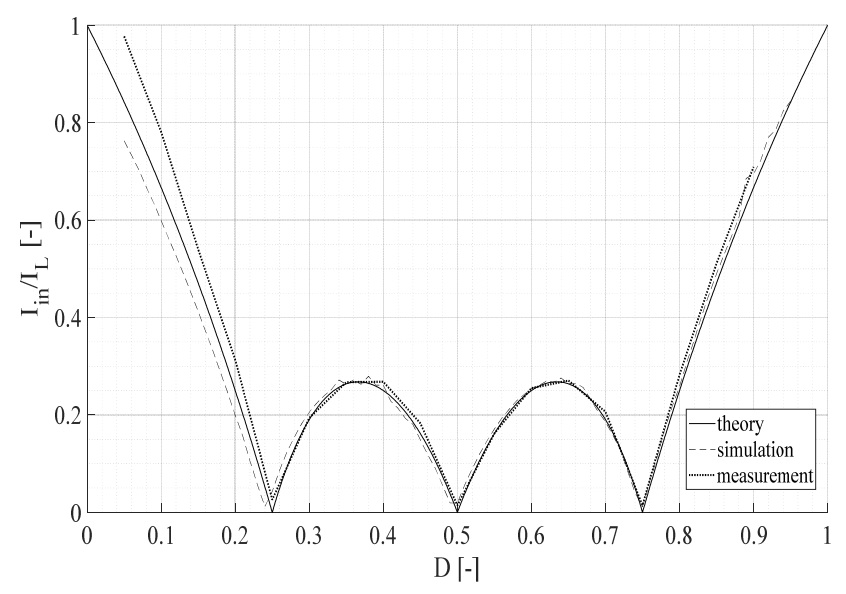

Fig. 13 The ratio of input current ripple to inductor current ripple

From Fig. 13 is seen that a preferable range of duty ratio is approximately from 0.2 to 0.8 , which is sufficient for almost all areas of use of boost converter.

The increasing of duty ratio causes that the $\mathrm{dc}$ component of current is also increasing, what is associated with increasing of $\mathrm{AC}$ component (the ripple) of the current. Then, in Fig. 13 states that not the ripple of the inductor current or the input current is shown, but only the ratio between them.

\section{CONCLUSION}

The four-phase interleaved boost converter operated in the continuous inductor current mode was analysed. Generalised expressions for the input and inductor current ripple were given in the theoretical part. Subsequently, the simulation and experimental results in the steady-state operation was examined. The comparison of theoretical, simulation and measured results is plotted in a graph. According to the graph, the optimal operation of the converter is around the duty ratio of $0.25,0.5,0.75$. In these time instants, the ripple of the input current is theoretically zero, but in practice is approximately zero. On the other side, while maintaining operating condition of the converter, the reduced inductor current ripple depends only on the value of $\mathrm{L}$ and therefore, if the ripples should be smaller the inductor value must be higher.

In the future work the determination of input and output capacities, determination of the optimal number of phases and phase shedding of the unloaded phases will be analysed.

\section{ACKNOWLEDGMENT}

This work was supported by projects: ITMS 26210120021, co-funded from EU sources and European Regional Development Fund, APVV-15-0571: Research of the optimum energy flow control in the electric vehicle system, VEGA 1/0928/15 - Research of electronic control of power transmission and motion of road ICE- hybrid $\mathrm{HEV}$ and EV vehicles.

\section{REFERENCES}

[1] TEXAS INSTRUMENTS, Power Tips: When to choose multiphase.

[2] BODO'S POWER SYSTEMS, Multiphase Buck Converters.

[3] OVCARCIK, R. - SPANIK, P. - PAVLANIN, R.: DC/DC converters used for a high input voltage based on a half-bridge topology, 6-th European Conference of TRANSCOM, Žilina, ISBN 80-8070417-1, pp. 57-62, 2005.

[4] SOMKUN, S. - SIRISAMPHANWONG, CH. SUKCHAI, S.: A DSP-based interleaved boost DCDC converter for fuel cell applications," International Journal of Hydrogen Energy, Vol. 40, Iss. 19, pp 6391-6404, May 2015.

[5] SUNDARI, N. - JEBA, D. - RAMALAKSHMI, R. RAJASEKARAN, R.: A Performance Comparison of Interleaved Boost Converter and Conventional Boost Converter for Renewable Energy Application," International Conference on Green High Performance Computing, IEEE, 2013, pp. 6, 2013.

[6] LAZIC, M. - ZIVANOV, N. - SASIC, B.: Design of Multiphase Boost Converter for Hybrid Fuel Cell/Battery Power Sources, Paths to Sustainable Energy, INTECH, pp. 359-404, 2010.

[7] ON SEMICONDUCTOR, Interleaved PFC.

[8] O’LOUGHLIN, M.: An Interleaving PFC PreRegulator for High-Power Converters, Texas Instruments,

[9] MUSAVI, F. - EBERLE, W. - DUNFORD, W. G.: A High-Performance Single-Phase Bridgeless Interleaved PFC Converter for Plug-in Hybrid Electric Vehicle Battery Chargers, IEEE Transactions on Industry Applications, Vol. 47, No. 4, 2011.

[10] WONG, P. L. - XU, P. - YANG, B. - LEE, F.C.: Performance Improvements of Interleaving VRMs with Coupling Inductors, IEEE Transactions on Power Electronics, Vol. 16, No. 4, 2001.

[11] CUBON, P. - RADVAN, R.: Evaluation of Propulsion System of the Electric Go-kart, 17th International Student Scientific Conference on 
Electrical Engineering, POSTER, Prague, ISBN 97880-01-05242-6, May 2013.

[12] MAZGUT, R. - CUBON, P. - RADVAN, R.: Possibilities optimizing energy consumption of electric vehicle, 19th International Student Scientific Conference on Electrical Engineering, POSTER, Prague, ISBN 978-80-01-05728-5, 2013.

[13] SHIN, H. B. - PARK, J. G. - CHUNG, S. K. - LEE, H. W.: Generalized Steady-state Analysis of Multiphase Interleaved Boost Converter with Coupled Inductors, IEE Proc.-Electr. Power Appl., Vol. 152, No. 3, 2005.

[14] IKRIANNIKOV, A.: The Benefits of the Coupled Inductor Technology, Maxim Integrated, Tutorial.

[15] IMAOKA, J. - YAMAMOTO, M. KAWASHIMA, T.: High-power-density three-phase interleaved boost converter with a novel coupled inductor, IEEJ Journal of Industry Applications, Vol. 1, No. 1, pp. 20-30.

Received September 27, 2017, accepted February 8, 2018

\section{BIOGRAPHIES}

Slavomir Kascak was born in Krompachy, Slovakia. He received the M.Sc. degree in power electronics and the D.Sc. degree in automation focused on electrical drives from the Faculty of Electrical Engineering of the University of Zilina, Slovakia, in 2010 and 2013, respectively. He is currently a Researcher and an Assistant
Professor in Department of Mechatronics and Electronics. His current research activities include power electronics, electrical drives, and control.

Michal Prazenica was born in 1985 in Zilina, Slovakia. $\mathrm{He}$ is graduated at the University of Žilina (2009). He received the Ph.D. degree in Power Electronics from the same university in 2012. He is now Research worker at the Department of Mechatronics and Electronics at the Faculty of Electrical Engineering, University of Zilina. His research interest includes analysis and modelling of power electronic systems, electrical machines, electric drives, and control.

Miriam Jarabicova was born in Zilina, Slovakia. She received the M. Sc. Degree in Telecommunication focused on telecommunication technics from the Faculty of Electrical Engineering of the University of Zilina, Slovakia in 1999. From 1999 to 2016 she was with Elteco company as a layout engineer specialist. She is currently an internal $\mathrm{PhD}$ student at the University of Zilina Department of Mechatronics and Electronics in the power electrical engineering study program. The main research interest is about power electronic systems.

Roman Konarik was born in Partizanske, Slovakia. He received the M.Sc. degree in Automation and Cybernetics from Brno University of Technology, Facult of Electrical Enginnering and Communications, in 2009. He is currently a PhD. Student at the Department of Mechatronics and Electronics at the Faculty of Electrical Engineering, University of Zilina. His current research activities include power electronics, electrical drives, and control. 